\title{
SYNTHESIS, SPECTRAL CHARACTERIZATION AND THERMAL BEHAVIOUR OF NEW METAL(II) COMPLEXES WITH SCHIFF BASE DERIVED FROM AMOXICILLIN
}

\author{
AURORA REISS*, ADRIANA SAMIDE, GEORGETA CIOBANU, IRINA DÄBULEANU
}

Department of Chemistry, Faculty of Mathematics and Natural Sciences, University of Craiova, 107i Calea Bucureşti, 200478 Craiova, Romania,

\begin{abstract}
Metal complexes of Schiff base derived from different antibiotics are widely employed as biological active materials, especially as antibacterial agents. Two new metal (II) complexes with the Schiff, base (HL) derived from amoxicillin and salicylaldehyde were synthesized and investigated using elemental analysis, spectroscopic techniques (IR and UV-Vis), conductometric and magnetic measurements. The IR spectra illustrated a bidentate ligand which coordinates through phenolic oxygen atom and imino nitrogen atom from azomethine bond. UV-Vis spectrophotometry showed the characteristic adsorption bands corresponding to an octahedral geometry for both metal complexes. The general formula established from experimental data was found to be $\left[\mathrm{ML}{ }_{2}\left(\mathrm{H}_{2} \mathrm{O}\right)_{2}\right](\mathrm{M}=\mathrm{Co}(\mathrm{II})$ and $\mathrm{Ni}(\mathrm{II}))$. This composition was further confirmed by thermal analysis and their thermal stability in nitrogen atmosphere was investigated. Antibacterial study showed that the efficiency of metal complexes is higher than the one found for the free Schiff base ligand.
\end{abstract}

Key words: Schiff base, amoxicillin, metal complexes, thermal analysis, antibacterial study

\section{INTRODUCTION}

Complexes with Schiff bases as ligands attract many researchers because of their wide application in medicinal chemistry, food industry, analytical chemistry, dye industry, catalysis, etc. and also for their simple methods to be prepared. Many studies reported several metal complexes of Schiff base derived from different antibiotics and their biological activity ${ }^{1-8}$. In all these cases it was found that metal complexes showed increased antimicrobial activity than their parent Schiff bases.

Amoxicillin $(2 S, 5 R, 6 R)-6-\{[(2 R)$-2-amino-2-(4-hydroxyphenyl)-acetyl $]$ amino -3,3-dimethyl-7-oxo-4-thia-1-azabicyclo[3.2.0] heptane-24-carboxylic acid) is a member of penicillin' $s$ group which are a very important class of $\beta$-lactamic antibiotics used to treat bacterial infections caused by microorganisms. The mechanism that makes bacteria resistant to $\beta$-lactams is due to the synthesis of $\beta$-lactamase enzymes which break the $\beta$-lactam ring and the antibiotic cannot bind to peptidoglycan layer'. Amoxicillin is sometimes combined with clavulanic acid, a $\beta$-lactamase inhibitor, to increase the spectrum of action against Gram-negative organisms, and to overcome bacterial antibiotic resistance mediated through $\beta$-lactamase production. From a coordination chemistry perspective it has been demonstrated that al the $\beta$-lactamic antibiotics possess a number of potential donor sites. Atoms involved in coordination and the structure of these complexes depend on several factors including reaction medium, $\mathrm{pH}$, temperature, solvents, etc. Iqbal M. et al. ${ }^{10}$ reported $\mathrm{Cu}(\mathrm{II})$ and $\mathrm{Zn}$ (II) complexes with Schiff base derived from amoxicillin and salicylaldehyde which were characterized by conventional methods such as microanalytical, magnetic and spectroscopic techniques associated with thermal analysis. Joshi S. et al. ${ }^{11}$ synthesized $\mathrm{Co}(\mathrm{II}), \mathrm{Zn}(\mathrm{II}), \mathrm{Ni}(\mathrm{II})$ and $\mathrm{Mn}$ (II) complexes with Schiff base derived from amoxicillin with two aldehydes - cinnamaldehyde and p-chlorobenzaldehyde - having improved antibacterial activity than the one that was found for free Schiff bases. Taghreed H.Al-Noor et al. ${ }^{12}$ synthesized mixed ligand complexes of $\mathrm{Fe}(\mathrm{II}), \mathrm{Co}(\mathrm{II}), \mathrm{Ni}(\mathrm{II}), \mathrm{Cu}(\mathrm{II})$, and $\mathrm{Zn}$ (II) containing Schiff base derived from amoxicillin and 4-dimethylaminobenzaldehyde with nicotinamide in 1:1:2 ratio. These synthesized complexes present relevant microbiological activity in comparison with the Schiff base.

As a part of our continuing efforts to synthesize and characterize Schiff base metal complexes ${ }^{13-15}$, in this paper we present the synthesis, infrared and UV-Vis spectra, thermal analysis and antibacterial study of new $\mathrm{Co}(\mathrm{II})$ and $\mathrm{Ni}(\mathrm{II})$ complexes with Schiff base derived from amoxicillin and salicylaldehyde (Figure 1.).

The paper was structured as follows: (i) introduction relates the state of art of topic; (ii) in experimental procedure, the methods of synthesis and the characterization techniques were described; (iii) the results were adequate discussed according to the experimental data obtained under our laboratory conditions and taking into consideration the known literature data; the results of antibacterial tests on Escherichia coli, Staphylococcus aureus and Pseudomonas aeruginosa were also commented based on detailed investigation which allowed the pertinent conclusions.

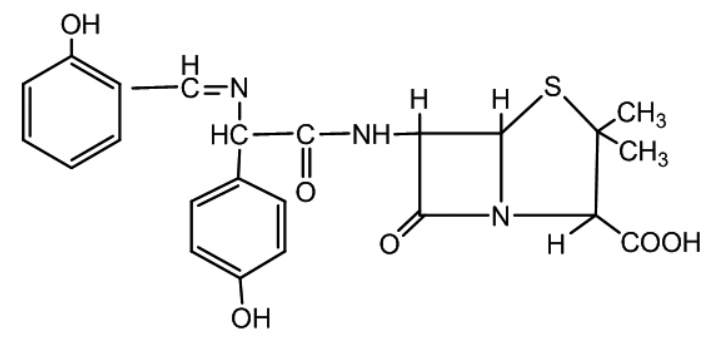

Figure 1. Structure of the Schiff base ligand (HL).

\section{EXPERIMENTAL}

\section{Materials and Methods}

Salicylaldehyde (Aldrich, Germany) and amoxicillin trihydrate (Iasi, Romania) were used to prepare the Schiff base that was mixed with (each) $\mathrm{Co}(\mathrm{II})$ and $\mathrm{Ni}(\mathrm{II})$ chloride (Merk, Germany) in order to synthesize their complexes. All reagents and chemicals were of analytical grade, commercially available, and were used without further purification.

The elemental analysis was performed with a Carlo Erba EA1108 elemental analyser. The metal content of the complexes was determined by atomic absorption technique using Varian-AA775 spectrophotomer. The IR spectra were recorded on a Perkin Elmer 157 instrument in anhydrous $\mathrm{KBr}$ pellets in the range $300-4200 \mathrm{~cm}^{-1}$. The UV-Vis spectra were carried out at room temperature in $10^{-3} \mathrm{~N}, \mathrm{~N}$-dimethylformamide (DMF) with the Unicam UV2-300 spectrometer. The molar conductivities were determined by using OK-102 conductometer. The magnetic susceptibility measurement was made on a Faraday balance, at room temperature, magnetic moments were thus calculated. The melting points were determined by using Sanyo Gallenkamp apparatus.

The thermal analysis was performed in nitrogen atmosphere, using a Diamond analyzer from Perkin-Elmer with Pyris software. The sample of 3.0 $\mathrm{mg}$ (for each) was heated in platinum crucibles in the temperature range from $R T$ (room temperature) to $1273 \mathrm{~K}$, with a heating rate of $10 \mathrm{~K} \mathrm{~min}^{-1}$. The thermal behaviour of both complexes was discussed according to TG/DTG/ DSC recorded curves.

Synthesis of the Schiff base ligand (HL)

Firstly, the Schiff base was prepared from $25 \mathrm{~mL}$ methanol containing $0,419 \mathrm{~g}(1 \mathrm{mM})$ amoxicillin and $15 \mathrm{~mL}$ methanol where has been dissolved in advance $0.61 \mathrm{~g}(1 \mathrm{mM})$ salicylaldehyde. In order to obtain the $p H$ value between 7 and $8,1.0 \mathrm{M} \mathrm{NaOH}$ solution was added and the mixture was refluxed a time of 2 hours. The volume of the solution was reduced to one half by evaporation when an orange precipitate was formed. It was filtered, washed with methanol and dried in vacuum at room temperature under anhydrous $\mathrm{CaCl}_{2}$. Recrystallization from a mixture of ethanol - water (50:50) gave the Schiff base; m.p. $192-194^{\circ}$ C. Analytical data: Schiff base: Found: C, 58.65; $\mathrm{H}, 4.87 ; \mathrm{N}, 8.87 \%$ Calcd. for $\mathrm{C}_{23} \mathrm{H}_{23} \mathrm{O}_{6} \mathrm{~N}_{3} \mathrm{~S}_{1}: \mathrm{C}, 58.84 ; \mathrm{H}, 4.90 ; \mathrm{N}, 8.95 \%$; Yield: $81 \%$. 


\section{Synthesis of the metal complexes}

The metal complexes were prepared in the same manner by mixing 2.0 mM Schiff base with $25 \mathrm{~mL}$ methanol containing $\mathrm{CoCl}_{2} 6 \mathrm{H}_{2} \mathrm{O}(1.0 \mathrm{mM})$ or $\mathrm{NiCl}_{2} 6 \mathrm{H}_{2} \mathrm{O}(1.0 \mathrm{mM})$. The mixtures $\mathrm{pH}$ value was adjusted to $7-8$ by adding $1.0 \mathrm{M} \mathrm{NaOH}^{2}$ solution and then they were refluxed a time of 2 hours. Finally, the volume of solutions was reduced to one half by evaporation, and in both cases, an occurrence of colored precipitate was observed this being assigned to $\mathrm{Co}$ (II) complex or $\mathrm{Ni}(\mathrm{II})$ complex respectively. It was filtered, washed with methanol and dried in vacuum. Recrystallization from hot methanol gave the metal complexes. Analytical data: $\mathrm{CoL}_{2}\left(\mathrm{H}_{2} \mathrm{O}\right)_{2}$ : color: reddish brown; m.p. $196-198^{\circ} \mathrm{C}$ Found: C, 53.51; H, 4.58; N, 8.12; Co, $5.67 \%$; Calcd. for $\mathrm{CoC}_{46} \mathrm{H}_{48} \mathrm{O}_{14} \mathrm{~N}_{6} \mathrm{~S}$ : C, 53.54; H, 4.65; N, 8.14; Co, 5.71\% ; Yield: $76 \%$; NiL2(H2O)2: color: brown; m.p. $200-202^{\circ} \mathrm{C}$ Found: C, 53.53; H, 4.62; N 8.04 ; $\mathrm{Ni}, 5.65 \%$; Calcd. for NiC46H48O14N6S 2 C, $53.55 ; \mathrm{H}, 4.65 ; \mathrm{N}, 8.14 ; \mathrm{Ni}$, $5.69 \%$; Yield: $85 \%$.

Antimicrobial studies

The newly synthesized metal complexes and the free Schiff base ligand were screened for antibacterial activity against pathogenic bacterial species Escherichia coli, Staphylococcus aureus, Pseudomonas aeruginosa and comparisons were made.

The paper disk diffusion method was adopted for the determination of antibacterial activity ${ }^{16}$. This method is simple and is routinely used in hospital laboratories.The ligand/complex $(30 \mu \mathrm{g})$ in DMF $(0.01 \mathrm{~mL})$ was placed on a paper disk with $3 \mathrm{~mm}$ in diameter with the help of a micropipette. The disks were left in an incubator for $48 \mathrm{~h}$ at $37^{\circ} \mathrm{C}$ and then were applied to the bacteria grown on agar plates. For the preparation of agar plates for bacterial species, Mueller-Hinton agar with $2 \%$ of glucose $(50 \mathrm{~g})$, obtained from Merck, was suspended in freshly distilled water $(1 \mathrm{~L})$. It was allowed to soak for $15 \mathrm{~min}$ and then was boiled in a water bath until the agar was completely dissolved. The mixture was autoclaved for $15 \mathrm{~min}$ at $120^{\circ} \mathrm{C}$, poured into sterilized petri dishes, and then stored at $40{ }^{\circ} \mathrm{C}$ for inoculation. Inoculation was performed with a platinum wire loop that was made red hot in a flame, cooled, and then used for the application of bacterial strains. Each paper disk was placed on an already inoculated agar plate which was then incubated at $37^{\circ} \mathrm{C}$ for $24 \mathrm{~h}$. Activity was determined by measuring the diameter of zones showing complete inhibition ( $\mathrm{mm})$.

\section{RESULTS AND DISCUSSION}

The Schiff base ligand was prepared by refluxing the appropriate amount of amoxicillin with salicylaldehyde in methanol and its structure was established by IR spectrum and microanalytical data (Figure 1). The metal complexes of Schiff base ligand were prepared by the stoichiometric reaction of the corresponding metal(II) chloride with the ligand in a molar ratio of 1 $: 2$. The complexes were obtained as air-stable amorphous solids which are insoluble in water, partially soluble in methanol and ethanol, totally soluble in $N, N$-dimethylformamide (DMF) and dimethyl sulfoxide (DMSO). The molar conductivities of the complexes measured in $10^{-3} \mathrm{M} \mathrm{DMF}$, at room temperature have low values of $13-18 \Omega^{-1} \mathrm{~cm}^{2} \mathrm{~mol}^{-1}$ indicating their non-electrolyte nature ${ }^{17}$. The elemental analysis above mentioned for both complexes leads to the following empirical molecular formula: $\mathrm{ML}_{2}\left(\mathrm{H}_{2} \mathrm{O}\right)_{2}$, where $\mathrm{M}=\mathrm{Co}(\mathrm{II})$ and $\mathrm{Ni}(\mathrm{II})$ and $\mathrm{L}=$ deprotonated Schiff base ligand.

\section{Infrared spectra}

IR spectra for amoxicillin trihydrate, Schiff base ligand and metal complexes were recorded in wavenumber range between $300-4200 \mathrm{~cm}^{-1}$. IR spectrum of amoxicillin trihydrate showed absorption bands at 3442, 3200, 1775 and $1688 \mathrm{~cm}^{-1}$ corresponding to $v(\mathrm{OH}), v\left(\mathrm{NH}_{2}\right), v(\mathrm{C}=\mathrm{O}) \beta$-lactam and $v(\mathrm{C}=\mathrm{O})$ amide stretching frequencies, respectively. A comparison of the IR spectra of amoxicillin trihydrate and Schiff base ligand provides proof of the formation of the Schiff base between amoxicillin and salicylaldehyde. The principal band responsible for this is the new absorption band at $1613 \mathrm{~cm}^{-1}$ attributed to $v(\mathrm{C}=\mathrm{N})$ stretching vibration; the bands attributed to $v(\mathrm{C}=\mathrm{O}) \beta$-lactam and $v(\mathrm{C}=\mathrm{O})$ amide are slightly shifted to 1770 and $1685 \mathrm{~cm}^{-1}$, respectively.

By comparing the IR spectra of the metal complexes with those of the free Schiff base it can be obtained the information about the bonding of the ligand to metal ions; as an example, in Figure 2 are shown IR spectra for Schiff base ligand and $\mathrm{Co}$ (II) complex. The most important absorption bands and their assignments are listed in Table 1.

The IR spectra of the complexes contains several absorption bands from the Schiff base and also, new absorption bands, these being attributed to the coordination of the ligand to metal ions through nitrogen atom from azomethine bond and oxygen atom from phenolic group.

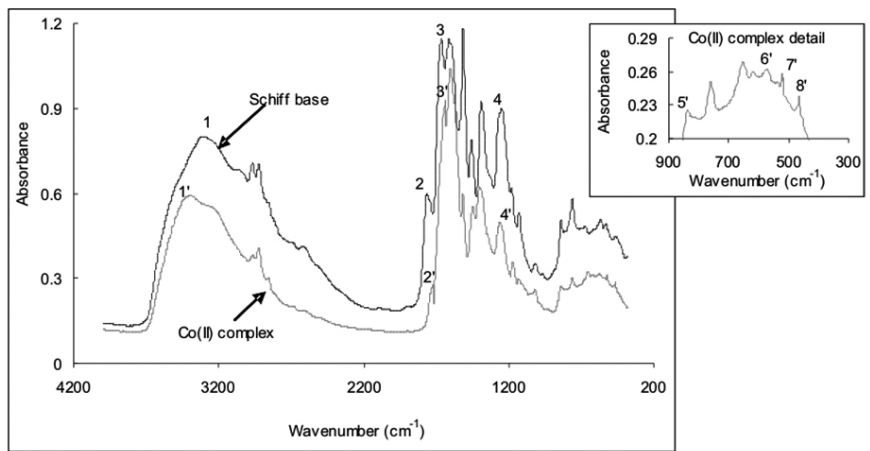

Figure 2. IR spectra for Schiff base and $\left[\mathrm{CoL}_{2}\left(\mathrm{H}_{2} \mathrm{O}\right)_{2}\right]$.

The main bands in the IR spectrum of the free Schiff base are at 3342, 1613 and $1252 \mathrm{~cm}^{-1}$ attributed to $v(\mathrm{OH}), v(\mathrm{C}=\mathrm{N})$ azomethine and $v(\mathrm{CO})$ phenolic, respectively. The band at $3342 \mathrm{~cm}^{-1}$ in the ligand spectrum disappears from the complexes as an indicative of phenolic group deprotonation. Instead, the band at $1252 \mathrm{~cm}^{-1}$ assigned to $v(\mathrm{CO})$ phenolic vibration is shifted by $17 \mathrm{~cm}^{-1}$ in comparison with the ligand, as a result of both deprotonation and coordination of phenolic oxygen. These shifts indicate the participation of the oxygen atom of the deprotonated hydroxyl group which is situated in a favorable position (orto) towards the azomethine group. The spectra of metal complexes exhibited a broad band around $3400 \mathrm{~cm}^{-1}$, which is assigned to water molecules, $v\left(\mathrm{H}_{2} \mathrm{O}\right)$, associated with the complexes. Coordinated water molecules exhibited $\rho \mathrm{r}\left(\mathrm{H}_{2} \mathrm{O}\right)$ rocking near $834,863 \mathrm{~cm}^{-1}$ and $\rho \mathrm{w}\left(\mathrm{H}_{2} \mathrm{O}\right)$ wagging near $567,541 \mathrm{~cm}^{-1}{ }_{18}^{18}$. IR spectra of the ligand presented a band at $1613 \mathrm{~cm}^{-1}$ attributed to $v(\mathrm{HC}=\mathrm{N})$ azomethine group, which is shifted to a higher value in both complexes at 1624 and $1630 \mathrm{~cm}^{-1}$ suggesting that the ligand is coordinated to the metal ion through nitrogen atom from azomethine group. The new absorption bands $v(\mathrm{MN})$ and $v(\mathrm{MO})$ observed in spectra of complexes at $530,534 \mathrm{~cm}^{-1}$ and $464,454 \mathrm{~cm}^{-1}$, respectively (see inserted spectrum in Figure 2) shows the coordination of the ligand through nitrogen and oxygen ${ }^{19}$.

Consequently, the IR spectra illustrate a bidentate ligand that coordinates through phenolic oxygen atom and imino nitrogen atom from azomethine bond. The coordination sphere of the metal is completed by the water molecules.

\section{UV-Vis spectra and magnetic measurements}

In order to obtain information regarding the coordination geometry of the complexes, the electronic spectra were determined at room temperature in DMF and the data obtained were correlated with magnetic moment values and ligand field parameters: splitting energy $(10 \mathrm{Dq})$, interelectronic repulsion parameter (B) and nephelauxetic ratio ( $\beta$ ) (Table 2). The electronic spectra of the ligand presents two absorption bands at 40260 and $32450 \mathrm{~cm}^{-1}$, respectively, attributed to $\pi \rightarrow \pi^{*}$ and $n \rightarrow \pi^{*}$, respectively, determined by the $\mathrm{C}=\mathrm{O}$ and $\mathrm{C}=\mathrm{N}$ groups. These absorption bands also appear in the electronic spectra of the complexes but they are shifted to lower values, which proves the coordination of the ligand to the central metallic ions ${ }^{20}$.

The electronic spectra of the Co(II) complex displays two bands at 10150 $\mathrm{cm}^{-1}\left(v_{1}\right)$ and $22125 \mathrm{~cm}^{-1}\left(v_{3}\right)$, which are assigned to $^{4} \mathrm{~T}_{\mathrm{gg}}(\mathrm{F}) \rightarrow^{4} \mathrm{~T}_{2 \mathrm{~g}}(\mathrm{~F})\left(\mathrm{v}_{1}\right)$; ${ }^{4} \mathrm{~T}_{10}(\mathrm{~F}) \rightarrow{ }^{4} \mathrm{~T}_{1 \mathrm{~g}}(\mathrm{P})\left(\mathrm{v}_{3}\right)$ transitions, respectively. These are the characteristic bands of high spin octahedral Co(II) complexes ${ }^{20}$. The ligand field parameters (Dq, $\mathrm{B}, \beta)$ are calculated using E. Koning equations ${ }^{21}$, when only $v_{3}$ and $v_{1}$ bands are observed in the electronic spectra and the values are well within the range reported for the octahedral complexes ${ }^{22}$. The value of the magnetic moment was $4.83 \mathrm{BM}$ for $\mathrm{Co}(\mathrm{II})$ complex which suggests three unpaired electrons in an octahedral environment ${ }^{23}$.

The electronic spectrum of $\mathrm{Ni}$ (II) complex presents two $\mathrm{d} \rightarrow \mathrm{d}$ absorption bands at 10720 and $16340 \mathrm{~cm}^{-1}$ in an octahedral environment corresponding to ${ }^{3} \mathrm{~A}_{2 \mathrm{~g}} \rightarrow{ }^{3} \mathrm{~T}_{2 \mathrm{~g}}(\mathrm{~F})\left(v_{1}\right)$ and ${ }^{3} \mathrm{~A}_{2 \mathrm{~g}} \rightarrow{ }^{3} \mathrm{~T}_{1 \mathrm{~g}}(\mathrm{~F})\left(v_{2}\right)$, transitions ${ }^{20}$. For $\mathrm{d}^{8}$ ions in an octahedral environment, the energy of $v_{1}$ corresponds to $10 \mathrm{Dq}$ and the value of Dq is obtained from $\mathrm{it}^{21}$. The values obtained for $\mathrm{Dq}, \mathrm{B}, \beta$ are in agreement with the experimental ones for $\mathrm{Ni}(\mathrm{II})$ octahedral complexes ${ }^{22}$. The magnetic moment value of $\mathrm{Ni}$ (II) complex is $3.12 \mathrm{BM}$ indicating the presence of two unpaired electrons on $\mathrm{Ni}(\mathrm{II})$ ion and suggesting that this complex has an octahedral geometry ${ }^{24,25}$. 
J. Chil. Chem. Soc., 60, № 3 (2015)

Table 1. Relevant IR data of the Schiff base $(\mathrm{L})$ and its metal complexes $\left(\mathrm{cm}^{-1}\right)$.

\begin{tabular}{|c|c|c|c|c|c|c|c|}
\hline Compound & $\begin{array}{c}v\left(\mathrm{H}_{2} \mathrm{O}\right) \\
\text { coord. }\end{array}$ & $v(\mathrm{OH})$ & $\begin{array}{c}v(\mathrm{C}=\mathrm{O}) \\
\text { carbox. }\end{array}$ & $\begin{array}{c}v(\mathrm{HC}=\mathrm{N}) \\
\text { azm. }\end{array}$ & $\begin{array}{c}v(\mathrm{CO}) \\
\text { phenolic }\end{array}$ & $\begin{array}{c}\delta_{\mathrm{r}}\left(\mathrm{H}_{2} \mathrm{O}\right) \\
\delta_{\mathrm{w}}\left(\mathrm{H}_{2} \mathrm{O}\right) \\
\text { coord. }\end{array}$ & $\begin{array}{c}v(\mathrm{MO}) \\
v(\mathrm{MN})\end{array}$ \\
\hline Schiff base (HL) & - & $3342(1)$ & $1719(2)$ & $1613(3)$ & $1252(4)$ & - & - \\
\hline$\left[\mathrm{CoL}_{2}\left(\mathrm{H}_{2} \mathrm{O}\right)_{2}\right]$ & $3395\left(1^{\prime}\right)$ & - & $1713\left(2{ }^{\prime}\right)$ & $1624\left(3^{\prime}\right)$ & $1235\left(4^{\prime}\right)$ & $\begin{array}{l}834\left(5^{\prime}\right) \\
567\left(6^{\prime}\right)\end{array}$ & $\begin{array}{c}530\left(7^{\prime}\right) \\
464\left(8^{\prime}\right)\end{array}$ \\
\hline$\left[\mathrm{NiL}_{2}\left(\mathrm{H}_{2} \mathrm{O}\right)_{2}\right]$ & 3397 & - & 1713 & 1630 & 1235 & 843541 & 534454 \\
\hline
\end{tabular}

* Numbers (1) - (4) and $\left(1^{\prime}\right)-\left(8^{\prime}\right)$ correspond to the peaks from Figure 1.

Table 2. Absorption maxima from electronic spectra and crystal field parameters for Schiff base (L) and its complexes.

\begin{tabular}{|c|c|c|c|c|c|}
\hline \multirow{2}{*}{ Compound } & \multirow{2}{*}{$\begin{array}{c}\text { Absorption } \\
\operatorname{maxima}\left(\mathrm{cm}^{-1}\right)\end{array}$} & \multirow{2}{*}{ Assignments } & \multicolumn{3}{|c|}{ Crystal field parameters } \\
\hline & & & 10Dq( $\left.\mathrm{cm}^{1}\right)$ & $\mathbf{B}\left(\mathrm{cm}^{-1}\right)$ & $\beta$ \\
\hline $\mathrm{L}$ & $\begin{array}{l}40260 \\
32450\end{array}$ & $\begin{array}{l}\pi \rightarrow \pi^{*} \\
\mathrm{n} \rightarrow \pi^{*}\end{array}$ & - & - & - \\
\hline$\left[\mathrm{CoL}_{2}\left(\mathrm{H}_{2} \mathrm{O}\right)_{2}\right]$ & $\begin{array}{c}38360 \\
29570 \\
22125\left(v_{3}\right) \\
10150\left(v_{1}\right)\end{array}$ & $\begin{array}{c}\pi \rightarrow \pi^{*} \\
\mathrm{n} \rightarrow \pi^{*} \\
{ }^{4} \mathrm{~T}_{\mathrm{gg}}(\mathrm{F}) \rightarrow{ }^{4} \mathrm{~T}_{1 \mathrm{~g}}(\mathrm{P}) \\
{ }^{4} \mathrm{~T}_{1 \mathrm{~g}} \rightarrow{ }^{4} \mathrm{~T}_{2 \mathrm{~g}}(\mathrm{~F})\end{array}$ & 1145 & 885 & 0.911 \\
\hline$\left[\mathrm{NiL}_{2}\left(\mathrm{H}_{2} \mathrm{O}\right)_{2}\right]$ & $\begin{array}{c}37360 \\
29870 \\
16340\left(v_{2}\right) \\
10720\left(v_{1}\right)\end{array}$ & $\begin{array}{c}\pi \rightarrow \pi^{*} \\
\mathrm{n} \rightarrow \pi^{*} \\
{ }^{3} \mathrm{~A}_{2 \mathrm{~g}} \rightarrow{ }^{3} \mathrm{~T}_{1 \mathrm{~g}}(\mathrm{~F}) \\
{ }^{3} \mathrm{~A}_{2 \mathrm{~g}} \rightarrow{ }^{3} \mathrm{~T}_{2 \mathrm{~g}}(\mathrm{~F})\end{array}$ & 1072 & 646 & 0.627 \\
\hline
\end{tabular}

Thermal analysis

The thermal analysis of both complexes was detailed as TG/DTG/DSC curves which are illustrated in Figure 3.
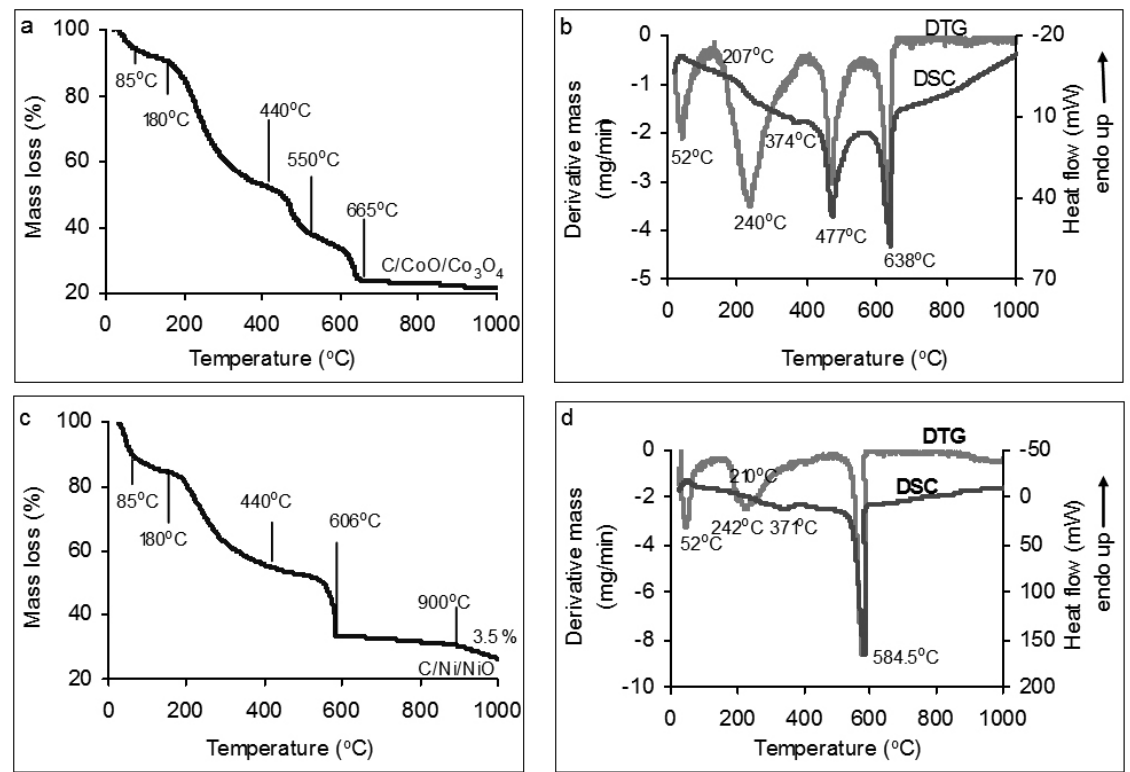

Figure 3. Thermoanalytical curves recorded for $\mathrm{Co}(\mathrm{II})$ and $\mathrm{Ni}(\mathrm{II})$ complexes: a - TG curve of $\mathrm{Co}(\mathrm{II})$ complex; b - DTG/DSC curves of Co(II) complex; c - TG curve of Ni(II) complex; d - DTG/ DSC curves of $\mathrm{Ni}(\mathrm{II})$ complex. 
It can be observed that, at low temperature up to $200{ }^{\circ} \mathrm{C}$, the events can be assigned to; (i) the elimination of some adsorbed gases and/or evaporation of the volatiles which were resulted during complexes synthesis; (ii) the removing of 2.0 moles of coordinated water, that is in good agreement with the expected mass loss (Figures 3a and 3c). The mass loss obtained for volatiles may be explained by the fact that the complexes were superficially dried in warm air at temperature below $40{ }^{\circ} \mathrm{C}$ to prevent alteration of complexes composition by accidentally loss of water. The endothermic effects on DSC curves can be observed as the shoulders with the maxima shifted to higher temperature values of $207^{\circ} \mathrm{C}$ and $210^{\circ} \mathrm{C}$, respectively (Figures $3 \mathrm{~b}$ and $3 \mathrm{~d}$ ) indicating an overlapping with other processes, most probable with the evaporation of physically adsorbed Schiff base on the particles of complexes. In temperature range between 180-
$440{ }^{\circ} \mathrm{C}$ the decomposition of both complexes takes place with the highest mass loss (Figures 3a and 3c), with the rupture of the coordination bonds between the metal and ligand or with the rupture of bonds from inside the ligand followed by the elimination of several by-products with the exothermic effects observed on DSC curves, at $374{ }^{\circ} \mathrm{C}$ and $371{ }^{\circ} \mathrm{C}$, respectively. Moreover, in this temperature range parallel courses could occur of Schiff base elimination and /or loss of one or the other Schiff base component. This would explain the appearance of peaks observed on the DTG curves at $240{ }^{\circ} \mathrm{C}$ and $242{ }^{\circ} \mathrm{C}$, respectively. Consequently, up to $440{ }^{\circ} \mathrm{C}$ a similar process of decomposition occurs for the both complexes, thus the decomposition events do not involve other outstanding remarks than those listed in Table 3.

Table 3. Characteristics of the thermodegradation steps of $\mathrm{Co}$ (II) and $\mathrm{Ni}$ (II) complexes.

\begin{tabular}{|c|c|c|c|c|c|c|c|}
\hline \multirow{2}{*}{ Complex } & \multirow{2}{*}{ Step } & \multirow{2}{*}{$\begin{array}{l}\text { Temperature } \\
\text { range } /{ }^{\circ} \mathrm{C}\end{array}$} & \multirow{2}{*}{$\begin{array}{c}\text { Thermal } \\
\text { effect }\end{array}$} & \multicolumn{2}{|c|}{ Maximum $/{ }^{\circ} \mathrm{C}$} & \multirow{2}{*}{$\begin{array}{l}\text { Mass } \\
\text { loss } / \%\end{array}$} & \multirow{2}{*}{ Associated process } \\
\hline & & & & DTG & DSC & & \\
\hline \multirow{7}{*}{$\mathrm{CoL}_{2}\left(\mathrm{H}_{2} \mathrm{O}\right)_{2}$} & 1 & RT-85 & Endo & 52 & 52 & 4.5 & $\begin{array}{l}\text { loss of adsorbed gases and/or adsorbed volatiles } \\
\text { resulted from synthesis }\end{array}$ \\
\hline & 2 & $85-180$ & Endo & \multicolumn{2}{|c|}{$\begin{array}{l}\text { shifted to } 207 \text { on } \\
\text { DSC curve }\end{array}$} & 3.8 & loss of coordinated water \\
\hline & 3 & $180-440$ & Exo & 240 & 374 & 40.8 & Schiff base decomposition \\
\hline & 4 & $440-550$ & Exo & 477 & 477 & 14.3 & decomposition of some by-products \\
\hline & 5 & $550-665$ & Exo & 638 & 638 & 12.8 & decomposition of some by-products \\
\hline & 6 & $665-1000$ & - & \multicolumn{2}{|c|}{ - } & 2.1 & $\begin{array}{l}\text { gradual loss of mass due to elimination of some } \\
\text { gases, such as } \mathrm{O}_{2}\end{array}$ \\
\hline & \multicolumn{5}{|c|}{ residue } & 21.7 & $65.6 \% \mathrm{C} ; 16.6 \% \mathrm{CoO} ; 17.8 \% \mathrm{Co}_{3} \mathrm{O}_{4}$ \\
\hline \multirow{6}{*}{$\mathrm{NiL}_{2}\left(\mathrm{H}_{2} \mathrm{O}\right)_{2}$} & 1 & RT-85 & Endo & 52 & 52 & 5.8 & $\begin{array}{l}\text { loss of adsorbed gases and/or adsorbed volatiles } \\
\text { resulted from synthesis }\end{array}$ \\
\hline & 2 & $85-180$ & Endo & \multicolumn{2}{|c|}{$\begin{array}{l}\text { shifted to } 210 \text { on } \\
\text { DSC curve }\end{array}$} & 3.9 & loss of coordinated water \\
\hline & 3 & $180-440$ & Exo & 242 & 371 & 36.3 & Schiff base decomposition \\
\hline & 4 & $440-606$ & Exo & 584.5 & 584.5 & 20.9 & decomposition of some by-products \\
\hline & 5 & $606-1000$ & - & & & 6.8 & $\begin{array}{l}\text { gradual loss of mass due to the elimination of some } \\
\text { gases, such as: } \mathrm{CO}, \mathrm{CO}_{2}\end{array}$ \\
\hline & \multicolumn{5}{|c|}{ residue } & 26.3 & $77.2 \% \mathrm{C} ; 17.8 \% \mathrm{NiO} ; 5.0 \% \mathrm{Ni}$ \\
\hline
\end{tabular}

At higher temperature than $440{ }^{\circ} \mathrm{C}$ the $\mathrm{Co}$ (II) complex decomposed in two steps (Figure 3a), followed by the exothermic effects with the temperature maxima nuanced on both DTG and DSC curves at $477{ }^{\circ} \mathrm{C}$ and $638{ }^{\circ} \mathrm{C}$, respectively (Figure 3b). After $665^{\circ} \mathrm{C}$, gradual mass loss with the small value of $2.1 \%$ takes place, and remaining a final residue of $21.7 \%$, suggesting that this could be composed of a mixture containing carbon and metal oxides, the latter being in equilibrium state, as shown in reaction I.

In the same temperature range the decomposition of $\mathrm{Ni}(\mathrm{II})$ complex takes place through a single step (Fig. 3c) with an exothermic effect at $584.5^{\circ} \mathrm{C}$ (Figure 3d), being in good agreement with the known literature data which showed that the nickel complexes is faster decomposed under high temperature than similar complexes of cobal $t^{26}$. After $606^{\circ} \mathrm{C}$ the mass loss has a higher value than that was recorded for $\mathrm{Co}$ (II) complex because in presence of carbon or $\mathrm{CO}$ the $\mathrm{Ni}$ oxide reduces to metal ${ }^{27,28}$ as reactions II and III show, final residue being of $26.3 \%$; this is consists of a mixture containing $\mathrm{C}$, Ni and $\mathrm{NiO}$. Similar events were reported for $\mathrm{Cu}(\mathrm{II})$ and $\mathrm{Zn}(\mathrm{II})$ complexes of Schiff bases obtained by condensation of amoxicillin and salicylaldehyde ${ }^{10}$. Other studies showed that amoxicillin was thermally decomposed at several stages with a total weight loss of $51.06 \%$, leaving a residual mass at $350^{\circ} \mathrm{C}$ of $48.94 \%$. Also, distinctive decomposition steps of complexes derived from salicylaldehide ${ }^{29}$ were presented. Moreover, similar assumptions were reported for residue composition related to thermal decomposition of other transition metal complexes under nitrogen atmosphere ${ }^{30}$.

M. Lalia-Kantouri ${ }^{31}$ showed that the by-products formed after the main degradation step (in our study after $400{ }^{\circ} \mathrm{C}$ ) are not stable and further heating of all the complexes at $700{ }^{\circ} \mathrm{C}$ leads to a residue consisting in a carbonaceous metal oxide ${ }^{30}$. The details for each studied compound are given in Table 3. Knowing that $\mathrm{CoO}$ converts to $\mathrm{Co}_{3} \mathrm{O}_{4}\left(\mathrm{CoO} \cdot \mathrm{Co}_{2} \mathrm{O}_{3}\right)$ if it is heated to around
600-700 ${ }^{\circ} \mathrm{C}$ and that above $900{ }^{\circ} \mathrm{C}, \mathrm{Co}_{3} \mathrm{O}$ decomposes to $\mathrm{CoO}^{29,30}$, the following equilibrium describes these reactions:

$$
2 \mathrm{Co}_{3} \mathrm{O}_{4} \rightleftarrows 6 \mathrm{CoO}+\mathrm{O}_{2}
$$

Based on this equilibrium and taking into consideration that $\mathrm{Co}$ (II) complex contains $5.7 \%$ Co which remains in final residue of $21.7 \%$, an algorithm to calculate the residue composition was applied. As shown in Scheme 1, " $\mathrm{x}$ " is attributed to moles of $\mathrm{Co}_{3} \mathrm{O}_{4}$ and "y" represents the carbon amount from final residue, at $1000^{\circ} \mathrm{C}$. By applying the corresponding molecular mass to $\mathrm{CoO}$ and $\mathrm{Co}_{3} \mathrm{O}_{4}$ the associated equations were deduced taking into consideration that the ratio of oxides is $3 / 1$, as shown in reaction $\mathrm{I}$.

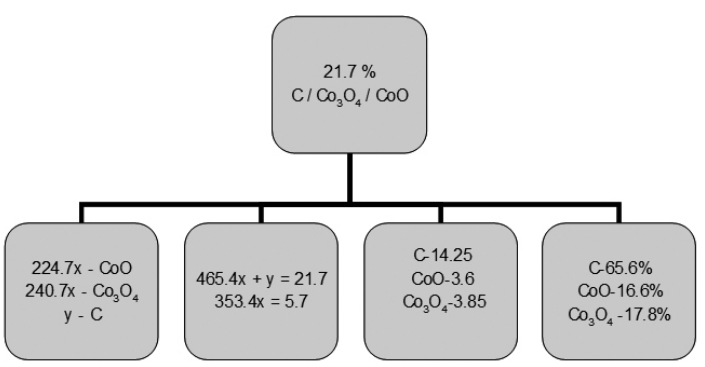

Scheme 1. The applied algorithm to calculate the residue composition for [Co(II) complex] thermal decomposition, up to $900^{\circ} \mathrm{C}$. 
In order to estimate the residue composition of $\mathrm{Ni}(\mathrm{II})$ complex the following reactions II and III are used. Based on the observation that in temperature range between $900-1000^{\circ} \mathrm{C}$, the mass loss is obviously greater, reaching a value of $3.5 \%$ (Figure $3 \mathrm{c}$ ) due to the $\mathrm{CO}_{2}$ elimination in the same amount, it can be observed that an equivalent number of moles $(0.0795)$ is attributed to $\mathrm{NiO}$ reduced at metallic $\mathrm{Ni}$.

$$
\begin{aligned}
& \mathrm{NiO}+\mathrm{C} \rightarrow \mathrm{Ni}+\mathrm{CO} \\
& \mathrm{NiO}+\mathrm{CO} \rightarrow \mathrm{Ni}+\mathrm{CO}_{2}
\end{aligned}
$$

The corresponding molecular mass and the Ni proportion from $\mathrm{NiO}$ were used to determine the composition of residue obtained at $\mathrm{Ni}$ (II) complex decomposition $(26.3 \%)$ at $1000{ }^{\circ} \mathrm{C}$ (Scheme 2$)$.

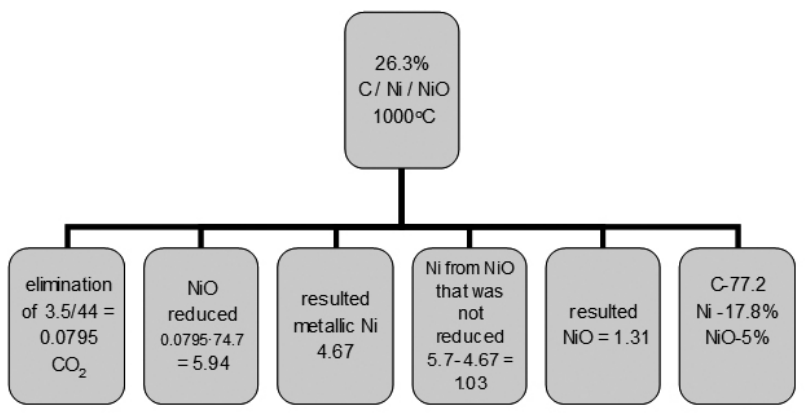

Scheme 2. The applied algorithm to calculate the residue composition for [Ni(II) complex] thermal decomposition, at $1000^{\circ} \mathrm{C}$.

Thermal degradation data of both complexes confirm the presence and the nature of water molecules and the stoichiometry of the studied meta complexes. The molecules of coordinated water released with an endothermic effect and the degradation process followed with an exothermic effect.

Based on analytical data, IR and UV-Vis spectra, and thermal analysis the proposed structure of the complexes is shown in Figure 4.

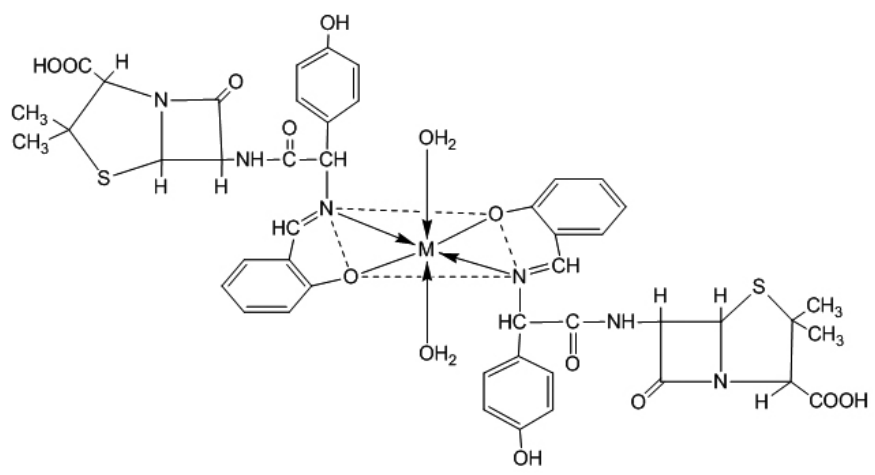

Figure 4. Structure of metal complexes where $\mathrm{M}=\mathrm{Co}(\mathrm{II})$ and $\mathrm{Ni}(\mathrm{II})$

\section{Antibacterial study}

The Schiff base and its complexes were tested for in vitro antibacterial activity using the diffusion method against E. coli, S. aureus, P.aeruginosa. The antibacterial activity was estimated on the basis of the size of inhibition zone formed around the paper disks on the seeded agar plates. Growth inhibition was compared with known antibiotics viz. ciprofloxacin. The results are presented in figure 5 .

The Schiff base and the complexes exhibited varying degrees of inhibitory effects on the growth of the tested bacterial species. As observed, the free Schiff base is moderately active against the bacterial species while the antibacteria activity of the Schiff base became more pronounced when it is coordinated to the metal ions. Referring to complexes, we note that the $\mathrm{Co}$ (II) complex is more active as compared with $\mathrm{Ni}(\mathrm{II})$ complex. In conclusion, the biological activity of the complexes follow the order: $\mathrm{Co}(\mathrm{II})>\mathrm{Ni}(\mathrm{II})>$ Schiff base ligand.

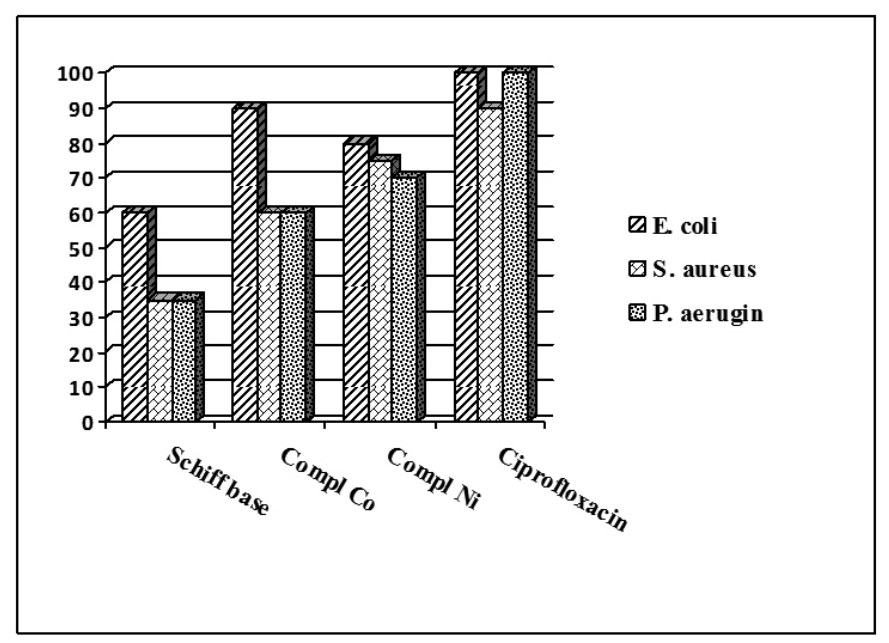

Figure 5. Biological activity of the Schiff base ligand and its complexes

Furthermore, the data show that $E$. coli was inhibited to a greater degree by the Co(II) complex. The complexes prepared with Schiff base derived from amoxicillin and salicylaldehide could reasonably be used for the treatment of some common diseases caused by E. coli.

An antibacterial activity of metal complexes better than the one of the Schiff base ligand can be explained on the basis of Overtone's and Tweedy's concepts $^{32,33}$. According to Overtone's concept of cell permeability, the lipid membrane that surrounds the cell favours only the passage of lipid soluble materials, therefore liposolubility is considered to be an important factor that controls the antibacterial activity. Drawing on chelation theory, Tweedy's concept explains the increase of lipophilic character of the metal chelate. Upon chelation, the positive charge of the metal ion is partially shared with the donor atom present on the ligand and a $\pi$-electron delocalization over the whole chelate ring takes place. In this way, the lipophilic character of the metal chelate increases and favours its permeation through the lipoid layers of the bacterial membranes and blocks the metal binding sites in the microorganism.

\section{CONCLUSIONS}

The new Co(II) and Ni(II) complexes with the Schiff base derived from amoxicillin and salicylaldehyde were synthesized and characterised. The data collected from IR spectra showed that the Schiff base behaves as a bidentate ligand coordinated in both complexes. Electronic spectra and magnetic measurements indicated an octahedral stereochemistry for the metal complexes. The thermal analysis presented the thermal degradation data of both complexes showing that the molecules of coordinated water were released with an endothermic effect and the degradation process was followed by an exothermic effect. Bacteriological studies were carried out against three species. The results showed increase in antimicrobial activity of metal complexes as compared with uncomplexed ligand.

\section{ACKNOWLEDGEMENTS}

The authors gratefully acknowledge Department of Clinic Laboratory from "Filantropia" Clinic Hospital, Craiova, Romania, in undertaking the antibacterial studies.

\section{REFERENCES}

1. J. R. Anacona, J.Estacio, Transition Met. Chem. 31, 227, (2006)

2. J. R. Anacona, C. J. Patino, Coord. Chem. 62, 613, (2009)

3. A. E. Ali, Spectrochim. Acta, Part A 78, 224, (2011)

4. D.Olea-Roman, J. C. Villeda-Garcia, R. Colorado-Peralta, A. SolanoPeralta, M. Sanchez, I. F. Hernandez- Ahuactzi, S. E. Castillo-blum, J. Mex. Chem. Soc. 57, 230, (2013)

5. Z. H. Chohan, C. T. Supuran, J. Enzyme Inhib. Med. Chem. 20, 463, (2005)

6. D.Tarinc, H. Muslu, M. Cesme, A.Golcu, M.Tumer, S. A. Ozkan, Current Anal. Chem. 9, 319, (2013) 
7. N.Raman J. Joseph, A. Sakthivel, R. Jeyamurugan, J. Chil. Chem. Soc., 54, 354, (2009).

8. N.Sultana, M. S. Arayne, M. Afzal, Pak. J. Pharm. Sci. 18, 36, (2005)

9. K. P. Fu, B. D. Foleno, S. C. Lafredo, J. M. LoCoco, D. M. Isaacson Antimicrob. Agents Chemother. 37, 301, (1993)

10. M. S. Iqbal, I. H.Bukhari, M. Arif Appl. Organometal. Chem. 19, 864, (2005)

11. S. Joshi, V.Pawar, V.Uma, International J. Pharma Bio Sciences, 2, 240, (2011)

12. H. Al-Noor Taghreed, R. A. Manhel, Al- Jeboori, T Ahmed, J. Chem. Pharm. Res. 6, 1225, (2014)

13. A. Reiss, Th.Căproiu, N.Stănica, Bull. Chem. Soc. Ethiop. 23, 63, (2009)

14. A.Reiss, S.Florea, Th. Căproiu, N.Stănica, Turkish J. Chem, 33, 775, (2009)

15. A. Reiss, M. C. Chifiriuc, E. Amzoiu, C. I. Spînu, Bioinorg. Chem. Applic. 2014, Article ID 926287, http://dx.doi.org/10.1155/2014/926287

16. E. Duca, M. Duca, Medical Microbiology, Ed., Didactica and Pedagogica, Bucharest, 1979.

17. J. W. Geary, Coord. Chem. Rev. 7, 81, (1971)

18. K. Nakamoto Infrared and Raman Spectra of Inorganic and Coordination Compounds, Ed., Wiley, New York, 1986.

19. M. Arif, M.M.R Qurashi, M.A.. Shad, J. Coord. Chem., 64, 1914, (2011)

20. A.B.P. Lever Inorganic Spectroscopy, Ed., Elsevier, Amsterdam, 1984.
21. E.Konig Structure and Bonding, 9, 175, (1971).

22. B. N. Figgis Introduction to Ligand Fields, Ed., John Wiley \& Sons, New York, 1976

23. Z.H.Chohan, C.T. Supuran, J. Enz. Inhib. Med. Chem. 19, 85, (2004)

24. N.Raman, S.Sobha L.Mitu J. Saudi Chem. Soc., 17, 151, (2013)

25. Q.-B. Li, L.-W. Xue, W.-C. Yang, G.-Q. Zhao, J. Chil. Chem. Soc., 58 , 1880, (2013).

26. I. Ripan, I.Ceteanu Metals Chemistry, Vol. 2, Ed., Didactica and Pedagogica, Bucharest, 1969.

27. C.Bisson-Boutelliez, S. Fontanay, C. Finance, F. Kedzierewicz, Pharm. Sci. Tech. 11, 574, (2010)

28. A. F. Petrovic, D. M. Petrovic, V. M. Leovac, M. Budimir, J. Therm. Anal. Calorim. 58, 589, (1999)

29. G.Brauer Handbook of Preparative Inorganic Chemistry, Ed., Academic Press, New York, 1963.

30. J.Leonard, L. Crescentini W. B. Fisher US4389339 (A) patent, "Process for making a cobalt oxide catalyst", 1979.

31. M. Lalia-Kantouri, J. Therm. Anal. Calorim., 82, 791, (2005)

32. N.Raman, A.Kulandaisamy, K.Jeyasubramanian, Polish J. Chem., 76 , $1085,(2002)$

33. M. R. Karekal, V. Biradar, M. B. H. Mathada, Bioinorg. Chem. Appl., 2013, Article ID 315972, http://dx.doi.org/10.1155/2013/315972 